\title{
The Quality of Instrument Used to Measure Mathematical Reasoning Ability of Junior High School Students
}

\author{
Sugeng ${ }^{1}$, P.M. Labulan ${ }^{2}$ \\ Faculty of Teacher Training and Education, Mulawarman University, Indonesia \\ sugeng@fkip.unmul.ac.id,pm_labulan@fkip.unmul.ac.id
}

\begin{abstract}
The quality of an instrument considerably determines the quality of the obtained data. The accuracy of a research finding is determined by the quality of its data. Therefore, the quality of one instrument determines the results of research. The quality of instrument used in measuring mathematical reasoning ability was analyzed by including 6 indicators of mathematical reasoning ability and involving 332 students of the Junior high school in Samarinda. They were selected by using Proportional Cluster Random Sampling method. The quality of instrument items was analyzed by using SPSS program and LISREL 8.8. The research findings showed that the instrument for mathematical reasoning ability had met the requirements of content validity, construct validity, moderate reliability coefficient, statistically significant discriminating power and moderate difficulty index. Therefore, this instrument had met the requirement of the instrument with a good quality.
\end{abstract}

Keywords-Mathematical, Reasoning, Ability

\section{INTRODUCTION}

In learning activities, there is a relationship between objectives, educational experiences and evaluation procedures. [1]. The effectiveness of the process in achieving instructional objectives can be identified through an evaluation procedure. One form of evaluation outcome is feedback on students' learning progress. The quality of feedback is considerably dependent on the quality of data or information which is obtained through the application of a measuring instrument. Thus, the quality of measurement instrument determines the quality of data or information that had been collected.

Based on the result of evaluation in schools, the eighth grade students' achievement in Math was still low (the average of 69.80) and this was below the Minimum Mastery Criteria (78) in one school in Samarinda Ulu Sub-district. One of the factors contributing to the low achievement was related to their mathematical reasoning ability. This was indicated by the fact that when the students were in the process of learning, they were not able to interpret the mathematical problems well, especially the question which needed an explanation. They also found difficulties when the mathematical problems were presented in a different way. This condition indicates that students still have low reasoning ability. Indeed, some students said that math lesson is difficult and uninteresting. In addition to reasoning ability factor, the quality of instrument used in measuring the students' learning achievement also contributes to the students' low achievement.

\section{REVIEW OF LITERATURE}

Measurement refers to the application of rules in order to give scores to the object to show the quantity of the object attribute [2]; or a systematic way to state an individual condition [3]. Therefore, a measurement activity is the application of number to an object by following certain rules to demonstrate the condition of the individuals being measured. According to the theory of measurement, the substance being measured must have only one dimension [4]; the investigation of un-dimensionality commonly uses Structural Equation Modeling Approach [5]. Moreover, the quality of a test also covers the requirement of validity, reliability, and objectivity [6]; or item difficulty, item discrimination, reliability, and validity [7]; as well as distracter analysis [8]. Validity can be in the forms of content validity and construct validity. Construct validity of one instrument can be seen from its construct, that is, measuring based on what has been planned and based on its underlying theories. The procedure of analyzing construct validity can be done through Factor Analysis with explanatory factors analysis [7]. This implies that achieving undimensionality of one instrument also means achieving construct validity of the instrument.

Mathematics is related to the exploration of mathematical concepts which are obtained from a study on space and number [9]. Space and number are abstract, meaning that math has an abstract object and they are organized from hierarchical concepts. The existing concepts are the foundation of the emergence of new concepts. The objects in the math lesson include facts, concepts, principles and skills [10]. In order to understand the concept of one particular mathematical material, it is required to understand the concept which precedes it by applying the pattern of deductive thinking. Soedjadi [11] stated that one of the mathematical characteristics is deductive thinking patterns. With its deductive thinking patterns, mathematics becomes a primary means of reasoning. Brodie [12] stated that "Mathematical reasoning is reasoning about and with the object of mathematics". This means that in mathematical reasoning, mathematics becomes a means as well as a subject of mathematical reasoning, especially deductive reasoning. This deductive reasoning skill underlies the 
emergence of inductive reasoning skill. These two forms of reasoning support one's success in understanding mathematical concepts.

Copi [13] stated: "Reasoning is a special kind of thinking in which inference takes place, in which conclusions are drawn from premises". Reasoning is related to high-order thinking activities in order to draw conclusions from premises or statements which are already known to be true. Reasoning consists of deductive and inductive reasoning. Deductive reasoning process starts from general knowledge to specific knowledge through the rules of arguments and syllogisms. The conclusions of deductive reasoning are valid if the premises are also valid, and vice versa. The process of deductive proof will involve mathematical theories or formulas which have been proved to be true deductively. In inductive reasoning, one can have new knowledge by observing surrounding nature and facts, and then drawing general conclusions. In inductive reasoning, the required premises are not known. Drawing conclusion in inductive reasoning is opposite to drawing conclusions in deductive reasoning.

Understanding mathematical materials required reasoning and the process of reasoning can be applied and trained through mathematics learning. This condition shows that mathematical materials and mathematical reasoning are two things which are related to each other. Therefore, the perception of students toward mathematical problems will influence their thinking patterns about mathematical problems and their solutions. Bloom, Madaus, \& Hastings [14] stated that cognitive domain covers: Knowledge, Comprehension, Application, Analysis, Synthesis, and Evaluation. These six levels of the intellectual ability really support the students' reasoning skill, especially when they are applying the process of analytic thinking.

Robbins \& Judge [15] stated that ability is a skill or a potential that someone possesses in accomplishing various tasks or jobs effectively. Ability consists of two types, namely (1) intellectual ability, that is, the ability which is required to do various mental activities, including reasoning and solving problems, and (2) physical ability), that is, the ability to accomplish jobs which require stamina, skills, power, and the like.

The level of students' mathematical reasoning ability can be identified through indicators of success. Based on [16] concerning the evaluation on the development of junior high school students, the indicators of reasoning ability as mathematic learning achievement can be identified as follows: (1) Making assumptions; (2) Doing mathematical manipulation; (3) Drawing conclusions, preparing proofs, giving reasons or proofs to the valid solutions; (4) Drawing conclusions from statements; (5) Investigating the validity of one argument; and (6) Identifying the patterns or the features of mathematical phenomena to make generalizations. Based on these conditions, students are considered being able to reason if they are able to make assumptions to the solution of a problem, able to do mathematical manipulation to make generalizations, preparing proofs or offering ideas from mathematical statements and able to draw conclusions.

The ability in mathematical manipulation refers to the students' ability in doing or accomplishing one problem so that the expected goals are achieved. The ability in drawing conclusions refers to the thinking process in which students empower their knowledge to bring about a thought or concept. Students' reasoning ability can also be seen from their ability to investigate the validity of an argument, that is, the ability which requires students to find out the validity of an existing statement. The ability to find the patterns or features of mathematical phenomena is required to make generalizations. In addition, reasoning ability is also needed to measure the success in identifying patterns of a statement to be developed into mathematical sentences.

Reasoning ability refers to one's skill in mastering thinking process in order to be able to draw conclusions. Therefore, mathematical reasoning ability of the students is measured by using a test of reasoning ability with the following indicators: (1) making assumptions; (2) doing mathematical manipulations; (3) drawing conclusions, preparing proofs to the validity of solutions; (4) drawing conclusions from statements; (5) investigating the validity of an argument; and (6) identifying the patterns of features of mathematical phenomena to make generalizations.

\section{RESEARCH METHOD}

This research was conducted in Samarinda and involved 332 students. The sample consisted of the students of SMPN 1, SMPN 4, SMPN 5, SMPN 22 Samarinda taken by using Proportional Cluster Random Sampling technique, (in which the sample was selected from the members of population randomly and proportionally). The size of the research sample was determined by using empirical formula given by [17], such as Eq. 1.

$$
S=\frac{X^{2} \cdot N \cdot P(1-P)}{d^{2}(N-1)+X^{2} P(1-P)}
$$

$\mathrm{S}$ is the sample size as the result of calculation; $\mathrm{N}$ is the size of population; $\mathrm{P}$ is the proportion of sample who answered the questions correctly; taken $\mathrm{P}=0,50$; $\mathrm{d}$ is the degree of accuracy which is reflected by the number of errors that can be tolerated in the fluctuation of sample proportion, in which the value of $d$ is $0.05 ; \mathrm{X} 2$ is table value of chi square for one degree of freedom relative to the desired level of confidence, which was 3.841 at the significance level of $\square=0.05$.

The result of this calculation determines the number of classes which were going to be used as research sample, namely 11 classes with the total of 332 students. The classes were taken randomly and the following classes were selected: (1) SMPN 1 Samarinda with the total of 78 students from grade VIIID, VIIIF, VIIIG; (2) SMPN 4 Samarinda with the total of 64 students from grade VIII5, VIII7; (3) SMPN 5 Samarinda with the total of 128 students from grade VIIID, VIIIH, VIIIJ, VIIIL; and (4) SMPN 22 Samarinda with 62 students from, grade VIIIG, VIIIJ.

The data of this research were collected by using an essay test. The test was used as an instrument to measure the students' achievement in Math. The test was constructed by the researchers using the materials for grade VIII of junior high school, consisting of 10 items of essay questions. Each 
question item was scored by using a scale of 0 to 10 , which means that the minimum score of each answer was 0 and the maximum score was 10 . The instrument was constructed based on the 6 indicators of reasoning which were stated in a test specification Table I.

TABLE I. TEST SPECIFICATION OF REASONING ABILITY

\begin{tabular}{|l|l|l|}
\hline Variable & Indicators & Item No. \\
\hline \multirow{5}{*}{$\begin{array}{l}\text { Reasoning } \\
\text { ability }\end{array}$} & Making assumptions & 1,2 \\
\cline { 2 - 3 } & Doing mathematical manipulations & 3 \\
\cline { 2 - 3 } & $\begin{array}{l}\text { Drawing conclusions, preparing proofs, } \\
\text { giving reasons or proofs to the validity } \\
\text { of solution }\end{array}$ & 4,5 \\
\cline { 2 - 3 } & Drawing conclusions from statements & 6,7 \\
\cline { 2 - 3 } & Investigating the validity of an argument & 8 \\
\cline { 2 - 3 } & $\begin{array}{l}\text { Identifying patterns or features of } \\
\text { mathematical phenomena to make } \\
\text { generalizations }\end{array}$ & 9,10 \\
\hline
\end{tabular}

The quality of the instrument was assessed in terms of difficulty index, discriminating power of each item, content validity, construct validity, and reliability of the test. To determine the difficulty index (DI), the following criteria were used: DI $>73 \%$ (Easy), $27 \% \leq \mathrm{DI} \leq 73 \%$ (Moderate), and DI $<$ $27 \%$ (Difficult). To determine the difficulty index of each test item, the following rule using Eq. 2.

$$
I k=\frac{D t+D r}{2 \cdot m_{n} n} x 100 \%
$$

Other data were analyzed by using SPSS program and LISREL 8.8 .

\section{RESULTS AND DISCUSSION}

\section{A. Content Validity}

Based on the specification of the instrument for measuring the students' mathematical reasoning ability, it was found that this specification had covered the types of variable, indicators to measure the objective achievement (behaviors), and the item numbers which were relevant to the indicators for mathematics materials. The entire questions (starting from number 1,2,3.., 10) were organized based on the specification of the instrument and each item number matched with its indicator. Therefore, the content validity was fulfilled.

\section{B. Construct Validity.}

Construct validity was assessed to prove if the items of mathematical reasoning ability was constructed based on its underlying theories. In addition, this assessment also intended to prove if the instrument for mathematical reasoning ability had met the unidimensional requirement. The assessment of unidimensional requirement for instrument was also to prove that the instrument measured only one type of trait latent, that it, students' reasoning ability in mathematic field.

The construct validity was assessed by using the sample size of 332 students with Structural Equation Modeling (SEM) approach with the help of LISREL 8.8 program. The operationalization of SEM used estimation method of $\mathrm{ME}=\mathrm{ML}$ (Maximum Likelihood). The result of SEM analysis was presented in a standardized condition Fig. 1. and in a T-value condition Fig. 2.

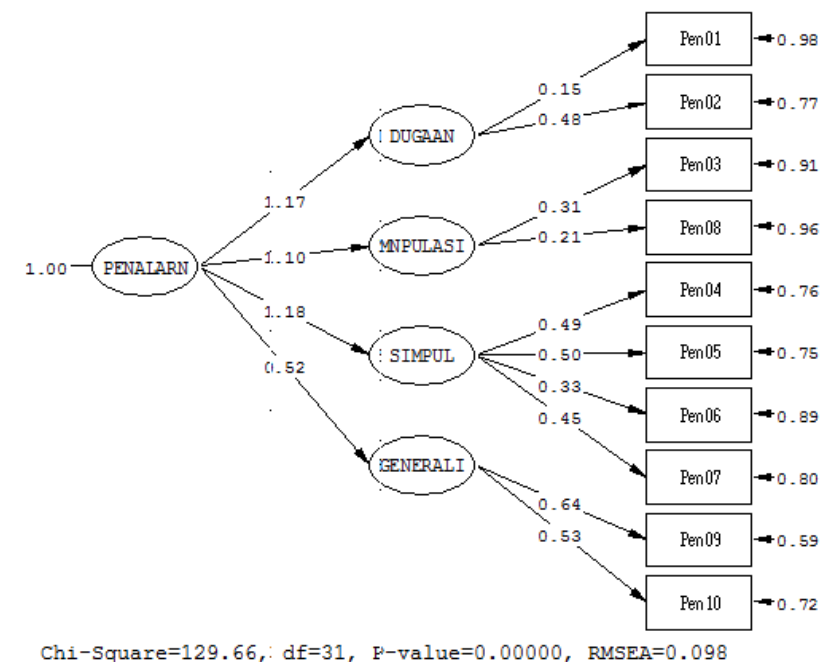

Fig. 1. The result of SEM analysis using LISREL Program (Standardized Condition)

Based on the result of SEM analysis for overall goodness of fit model, it was found that the value of Goodness of Fit Index or GFI $=0.93$. By fulfilling one requirement of this Goodness of fit (even though the value of RMSEA $=0.098$, slightly higher than 0.08; and only Goodness of Fit Index which was higher than 0.90); the overall model fitted between data and measurement model [18].

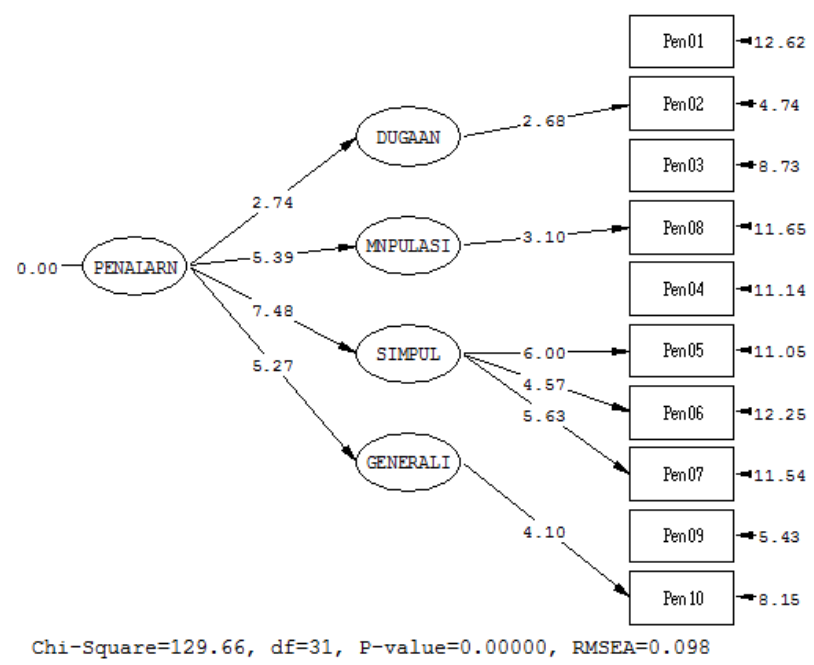

Fig. 2. The result of SEM Analysis with LISREL program (T-value Condition)

Moreover, the result of Goodness of fit test for the model based on the predicted parameter testing (Lambda, Gamma, Beta, Delta, Epsilon) for the model of T-value showed a significant result for the entire model. This condition indicated that construct validity had been met, meaning that the 
instrument had been constructed based on its underlying theories and the unidimensional requirement for the instrument had also been met.

\section{Discriminating Power}

Item discriminating power index for mathematical reasoning ability was identified by using t-test analysis [19] with the help of SPSS program. Item discriminating power was investigated by determining the statistically significant difference of mathematical reasoning ability between upper group and lower group. An item can be categorized as having a good discriminating power if the result of t-test is significant at the significance level of $\alpha$. The result of t-test analysis can be seen on Table II.

Discriminating power index is shown by whether the result of t-test is significant or not. The result of analysis showed that all items in the test instrument for students' mathematical reasoning ability were statistically significant at $\alpha=5 \%$. Therefore, all of the items were able to discriminate mathematical reasoning ability between students with low ability and those with high ability.

TABLE II. ITEM DESCRIMINATING POWER INDEX

\begin{tabular}{|l|l|l|l|l|}
\hline $\begin{array}{l}\text { Items of } \\
\text { Instrument }\end{array}$ & t-computed & Stat.Sig. & $\begin{array}{l}\text { Sig.Level } \\
\alpha=5 \%\end{array}$ & Conclusion \\
\hline Item 1 & 3.707 & 0.000 & 0.05 & Significant \\
Item 2 & 12.011 & 0.000 & 0.05 & Significant \\
Item 3 & 6.377 & 0.000 & 0.05 & Significant \\
Item 4 & 5.973 & 0.000 & 0.05 & Significant \\
Item 5 & 6.302 & 0.000 & 0.05 & Significant \\
Item 6 & 10.387 & 0.000 & 0.05 & Significant \\
Item 7 & 13.666 & 0.000 & 0.05 & Significant \\
Item 8 & 5.270 & 0.000 & 0.05 & Significant \\
Item 9 & 6.333 & 0.000 & 0.05 & Significant \\
Item 10 & 5.756 & 0.000 & 0.05 & Significant \\
\hline
\end{tabular}

\section{Reliability}

Coefficient of reliability was tested by using Cronbach's Alpha with the help of SPSS program and the result of the analysis is as follows.

\section{Reliability Statistics}

\begin{tabular}{|c|r|}
\hline $\begin{array}{c}\text { Cronbach's } \\
\text { Alpha }\end{array}$ & N of Items \\
\hline .622 & 10 \\
\hline
\end{tabular}

Based on the result of analysis with the help of SPSS, the coefficient of reliability using Cronbach's Alpha was 0.622 for 10 question items in the instrument of students' mathematical reasoning ability. The coefficient of reliability was categorized as moderate.

\section{E. Difficulty Index}

The instrument for students' mathematical reasoning ability used essay question items. The result of analysis for its difficulty index can be seen on Table III as follows:
The result of analysis showed that all test items had moderate difficulty index. This condition indicated that all items were feasible to use for collecting further data.

TABLE III. THE RESUlT OF DIFFICULTy INDEX ANALYSIS

\begin{tabular}{|l|l|l|l|l|l|}
\hline \multicolumn{5}{|l|}{ Difficulty Index for 27\% of students in group } \\
\hline $\begin{array}{l}\text { Item } \\
\text { No. }\end{array}$ & $\mathrm{m}$ & $\mathrm{Dt}$ & $\mathrm{Dr}$ & $\mathrm{Ik}$ & Conclusion \\
\hline 1 & 10 & 60 & 19 & $49 \%$ & Moderate \\
2 & 10 & 50 & 16 & $41 \%$ & Moderate \\
3 & 10 & 72 & 43 & $72 \%$ & Moderate \\
4 & 10 & 74 & 34 & $68 \%$ & Moderate \\
5 & 10 & 74 & 38 & $70 \%$ & Moderate \\
6 & 10 & 74 & 39 & $71 \%$ & Moderate \\
7 & 10 & 74 & 40 & $71 \%$ & Moderate \\
8 & 10 & 80 & 10 & $56 \%$ & Moderate \\
9 & 10 & 74 & 37 & $69 \%$ & Moderate \\
10 & 10 & 72 & 42 & $71 \%$ & Moderate \\
\hline
\end{tabular}

A qualified measurement tool is needed in measurement practice. Such tool will help obtain accurate research data so that the information provided is also accurate. The research findings showed that the instrument for measuring mathematical reasoning ability has met the requirements of content validity, construct validity, reliability with a moderate reliability, statistically significant discriminating power for each item, and moderate difficulty index. Therefore, this instrument can be categorized as an instrument with a good quality. The application of this instrument in measurement practice is expected to bring about more accurate data so that the information given is also accurate.

Reasoning ability covers various indicators such as follows: (1) making assumptions; (2) doing mathematical manipulations; (3) drawing conclusions, preparing proofs, giving reasons or proofs to the validity of solutions; (4) drawing conclusions from statements; (5) investigating the validity of arguments; and (6) identifying patterns or features from mathematic phenomena to make generalizations. In mathematic field, reasoning ability with these 6 indicators is suitable with the need of the students to think mathematically. This condition supports the research findings on reasoning ability in mathematic field. A research finding from [20] showed that reasoning ability affected students' ability in solving questions at the VII grade of MTs Nurul Huda Mangkang Semarang with the percentage of $22.9 \%$.

The quality of instrument for mathematical reasoning ability was analyzed by using quantitative approach. This approach gives an emphasis on numeric/quantity aspect. The analysis can be done in different way, using qualitative approach, including an analysis on the aspects of (a) test materials, (b) test construction, and (c) language.

\section{CONCLUSION}

The result of data analysis which included content validity, construct validity, discriminating power, reliability, and difficulty index of the instrument for students' mathematical reasoning ability showed that the instrument had fulfilled the requirement as a good instrument. The application of one instrument to collect data needs to be analyzed in order to 
obtain an quality instrument. The quality aspects of analysis are diverse depending on the types of instrument, measurement approach used and so forth.

\section{REFERENCES}

[1] W. A. Mehrens \& I. J. Lehmann, "Measurement and evaluation in education and psychological (2nd ed.)". New York: Holt, Rinehart, and Winston, 1978, p.11.

[2] J. C. Nunnally, "Psychometric theory". New York: McGraw-Hill, 1978.

[3] M. J. Allen, \& W. M. Yen, "Introduction to measurement theory". Long Grove, Il: Waveland Press, Inc, 1979.

[4] R. K. Hambleton, H. Swaminathan, \& H. J. Rogers, "Fundamentals of item response theory". Newbury Park, CA: Sage Publications, 1991, p. 3.

[5] M. Wilson, "Comparing attitude across different Cultures: Two Quantitative Approaches to Construct Validity. In Objective Measurement: Theory and Practice", Volume 2. Edited by mark Wilson. Norwood, New Jersey: Ablex Publishing Corporation, 1994, pp. 271291.

[6] L. W. Anderson, "Classroom Assessment. Enhancing the Quality of Teacher Decision Making". New Jersey, mahwah: Lawrence Erlbaum Associates Publishers, 2003, p. 10.

[7] L. Crocker \& J. Algina, "Introduction to Classical and Modern Test Theory". New York: Holt, Rinehart and Winston, 1986, pp. 311-316.

[8] C. R. Reynolds, R. B. Livingstone, \& V. Willson, "Measurement and assessment in education (2nd ed.)", 2009, pp. 148-150.

[9] P. J. Eccles, "An Introduction to Mathematical Reasoning number, sets, and functions". Cambridge: Cambridge University Press., 2007, p. 1.
[10] E. G. Begle, "Critical Variables in Mathematics Education: Findings from a Survey of the Empirical Literature". Washington D.C.: Mathematical Association of America. National Council of Teachers of Mathematica, 1979, pp. 6-8.

[11] R. Soedjadi,. "Kiat pendidikan matematika di Indonesia. Konstatasi keadaan masa kini menuju harapan masa depan”. Jakarta: Depdiknas, Ditjen Dikti, 2000, p. 10.

[12] K. Brodie, "Teaching Mathematical Reasoning in Secondary School Classroom". New York: Springer, 2010, p. 7.

[13] I. M. Copi, "Introduction to Logic". New York: Macmillan, 1978, p. 5.

[14] B. S. Bloom, G. F. Madaus, \& J. T. Hastings, "Evaluation to improve learning". New York: McGraw-Hill Book Company, 1981, pp. 331-333.

[15] S. P. Robbins, \& T. A. Judge, "Organizational Behavior, 13th Edition". Pearson Education, Inc., Upper Saddle River, New Jersey, 2009, pp. 5761.

[16] Petunjuk Teknis Peraturan Dirjen Dikdasmen Depdiknas Nomor 506/C/Kep/PP/2004 tanggal 11 Nopember 2004.

[17] S. Isaac \& W. B. Michael, "Handbook in research and evaluation (2nd ed.)". San Diego, California 92107: EdiTS Publisher, 1984, p. 192.

[18] Imam Ghazali, "Structural Equation Modeling. Teori, Konsep, dan Aplikasi dengan Program LISREL 8.80". Semarang: Badan Penerbit Universitas Diponegoro, 2008, p. 31

[19] Subino, "Konstruksi dan analisis tes: Suatu pengantar kepada teori tes dan pengukuran". Jakarta: Ditjen Dikti, 1987, p. 100.

[20] Nailil Faroh, "Pengaruh Kemampuan Penalaran dan Komunikasi Matematika terhadap Kemampuan Menyelesaikan Soal Cerita Materi Pokok Himpunan pada Peserta Didik Semester 2 Kelas VII MTs NU Nurul Huda Mangkang Semarang Tahun Pelajaran 2010/2011. Semarang: Institut Agama Islam Negeri Walisongo, 2011. (Diakses pada tanggal 19 Februari 2014 dari http://library. walisongo.ac.id/digilib/ files/disk1/130/jptiain-gdl-nailil-faro-6482-1-pdf. 